STREAMFLOW, SPECIFIC-CONDUCTANCE, AND TEMPERATURE DATA FOR BAYOU AND

LITTLE BAYOU CREEKS NEAR PADUCAH, KENTUCKY, AUGUST 15 AND 16, 1989

By Ronald D. Evaldi, and Dennis L. McClain

U.S. GEOLOGICAL SURVEY

Open-File Report 89-582

Prepared in cooperation with the

U.S. DEPARTMENT OF ENERGY

Louisville, Kentucky

1989

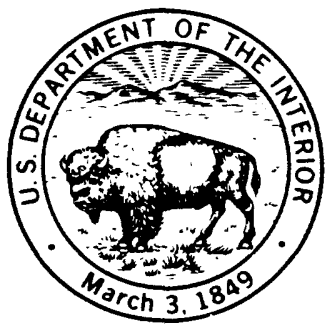




\author{
DEPARTMENT OF THE INTERIOR \\ MANUEL LUJAN, JR., Secretary \\ U.S. GEOLOGICAL SURVEY \\ Dallas L. Peck, Director
}

For additional information write to:

District Chief

U.S. Geological Survey

2301 Bradley Avenue

Louisville, Kentucky 40217
Copies of this report may be purchased from:

U.S. Geological Survey Books and Open-File Reports Box 25425

Federal Center, Building 810 Denver, Colorado 80225 


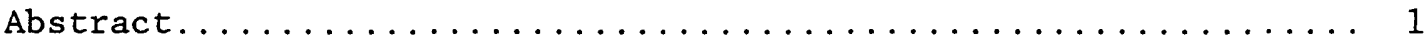

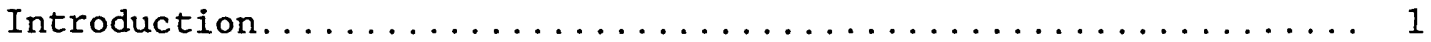

Description of study area..................... 1

Hydrologic conditions....................... 4

Streamflow............................... 4

Specific conductance........................ 12

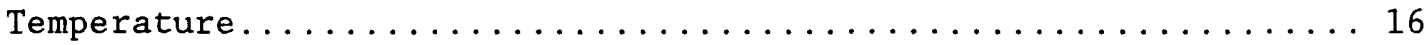

References................................ 19

\section{ILLUSTRATIONS}

Figure 1. Map showing location of the study area........ 2

2. Diagram showing a generalized geologic section in the vicinity of the Shawnee Steam Plant..... 3

3. Map showing location of measurement sites in the Bayou Creek and Little Bayou Creek watersheds, August 15 and $16,1989 \ldots \ldots \ldots \ldots 7$

Figures 4-11. Graphs showing:

4. Discharge of Little Bayou Creek, August 15, 1989.. 8

5. Discharge of Little Bayou Creek, August 15, 1989, with upstream and tributary flow subtracted.... 9

6. Discharge of Bayou Creek, August 16,1989...... 11

7. Discharge of Bayou Creek, August 16, 1989, with upstream and tributary flow subtracted.... 13

8. Specific conductance in the Little Bayou Creek watershed, August 15, 1989.......... 14

9. Specific conductance in the Bayou Creek watershed, August $16,1989 \ldots \ldots \ldots \ldots \ldots \ldots$

10. Temperature in the Little Bayou Creek watershed, August 15, 1989............ 17

11. Temperature in the Bayou Creek watershed,

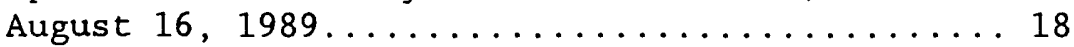

TABLES

Table 1. Discharge, specific-conductance, and temperature measurements in the Little Bayou Creek watershed, August 15, 1989.................... 6

2. Discharge, specific-conductance, and temperature measurements in the Bayou Creek watershed,

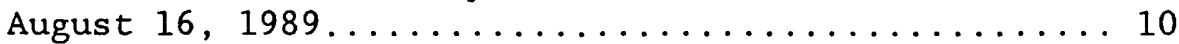


FACTORS FOR CONVERTING INCH-POUND UNITS

TO INTERNATIONAL SYSTEM OF UNITS (SI)

\section{Multiply}

cubic foot per second $\left(\mathrm{ft}^{3} / \mathrm{s}\right)$

foot ( $f t$ )

mile (mi)

micromhos per centimeter at

$25^{\circ} \mathrm{Celsius}\left(\mu \mathrm{mhos} / \mathrm{cm}\right.$ at $25^{\circ} \mathrm{C}$ ) by

0.02832

0.3048

1.609

1.000

\section{To obtain}

cubic meter per second $\left(\mathrm{m}^{3} / \mathrm{s}\right)$ meter (m)

kilometer $(\mathrm{km})$

microsiemens per centimeter at $25^{\circ} \mathrm{Celsius}\left(\mu \mathrm{S} / \mathrm{cm}\right.$ at $\left.25^{\circ} \mathrm{C}\right)$

\footnotetext{
To convert degree Fahrenheit $\left({ }^{\circ} \mathrm{F}\right)$ to degree Celsius $\left({ }^{\circ} \mathrm{C}\right)$ : ${ }^{\circ} \mathrm{C}=\left({ }^{\circ} \mathrm{F}-32\right) / 1.8$
}

Sea leve1: In this report "sea level" refers to the National Geodetic Vertical Datum of 1929 (NGVD of 1929)--a geodetic datum derived from a general adjustment of the first-order level nets of both the United States and Canada, formerly called "Sea Level Datum of 1929". 


\title{
STREAMFLOW, SPECIFIC-CONDUCTANCE, AND TEMPERATURE DATA FOR BAYOU AND LITTLE BAYOU CREEKS NEAR PADUCAH, KENTUCKY, AUGUST 15 AND 16, 1989
}

\author{
By Ronald D. Evaldi and Dennis L. McClain
}

\begin{abstract}
Discharge, temperature, and specific conductance measurements were made August 15 and 16, 1989, at 74 main channel sites and seven tributaries on Bayou and Little Bayou Creeks in the vicinity of the Paducah Gaseous Diffusion Plant. These measurements were made during base flow conditions to provide data for analysis of the interaction of surface and ground water. The discharge of Bayou Creek was 0.30 cubic feet per second ( $\mathrm{ft}^{3} / \mathrm{s}$ ) at the most upstream site, and $5.8 \mathrm{ft}^{3} / \mathrm{s}$ at the most downstream site. Total measured tributary inflow of Bayou Creek was $5.7 \mathrm{ft}^{3} / \mathrm{s}$. Specific conductance values in the Bayou Creek watershed ranged from 208 to 489 microsiemens per centimeter $(\mu \mathrm{S} / \mathrm{cm})$, and water temperature ranged from 20.0 to 32.6 degrees Celsius $\left({ }^{\circ} \mathrm{C}\right)$. The discharge of Little Bayou Creek was $0.65 \mathrm{ft}^{3} / \mathrm{s}$ at the most upstream site, and $1.8 \mathrm{ft}^{3} / \mathrm{s}$ at the most downstream site. Total measured tributary inflow of Little Bayou Creek was $0.38 \mathrm{ft}^{3} / \mathrm{s}$. Specific conductance values in the Little Bayou Creek watershed ranged from 211 to $272 \mu \mathrm{S} / \mathrm{cm}$, and water temperature ranged from 14.5 to $24.9^{\circ} \mathrm{C}$.
\end{abstract}

\section{INTRODUCTION}

Discharge, specific conductance, and temperature of streams in the Little Bayou Creek and Bayou Creek watersheds (fig. 1) near the Paducah Gaseous Diffusion Plant were measured August 15 and 16, 1989, by the U.S. Geologica1 Survey. These measurements were made as part of a seepage study during base flow conditions to provide data for analysis of the interaction of surface and ground water. These measurements were conducted in cooperation with the Department of Energy as part of their effort to evaluate surface- and groundwater flow routes near the plant.

\section{Description of the study area}

Little Bayou Creek and Bayou Creek in McCracken County, Kentucky, drain northward to the Ohio River just west of the Shawnee Steam Plant (fig.1). The topography in the drainage basins is gently rolling. Bayou Creek drains the western side of the Paducah Gaseous Diffusion Plant site and Little Bayou Creek drains the eastern side. Little Bayou Creek joins Bayou Creek about 0.2 miles upstream of its confluence with the Ohio River.

The study area is in the Jackson Purchase region of Kentucky which is the northern tip of the Mississippi Embayment of the Gulf Coastal Plain. The area is underlain by unconsolidated deposits of gravel, sand, silt, clay, and loess. These unconsolidated deposits are underlain by limestone, chert, and shale. The generalized geologic section (fig.2), modified from Hanson (1966), 


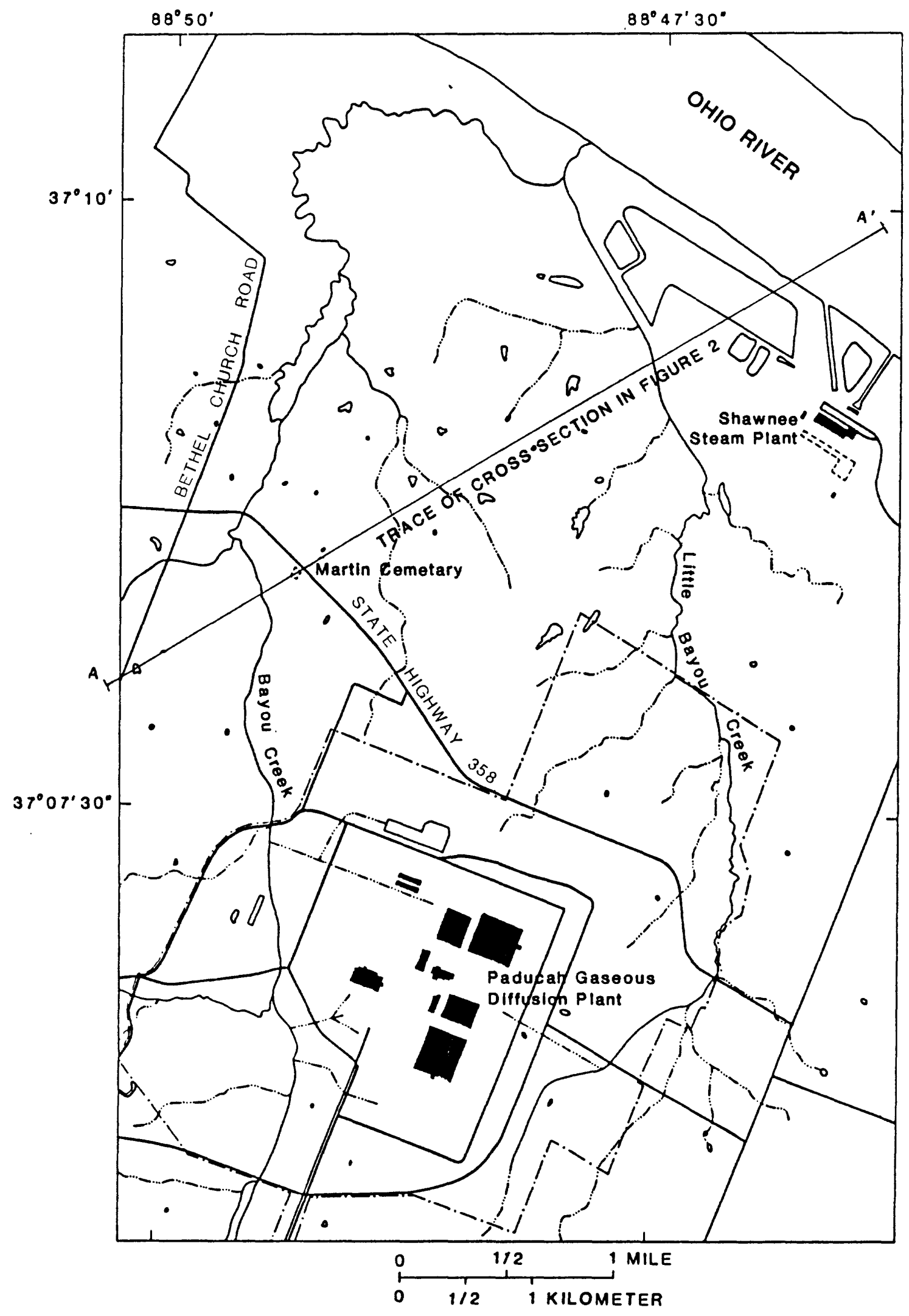

Base from U.S.Geological Survey 1:24,000. Heath, 1978 , Joppa, 1982.

Figure 1.--Location of study area 


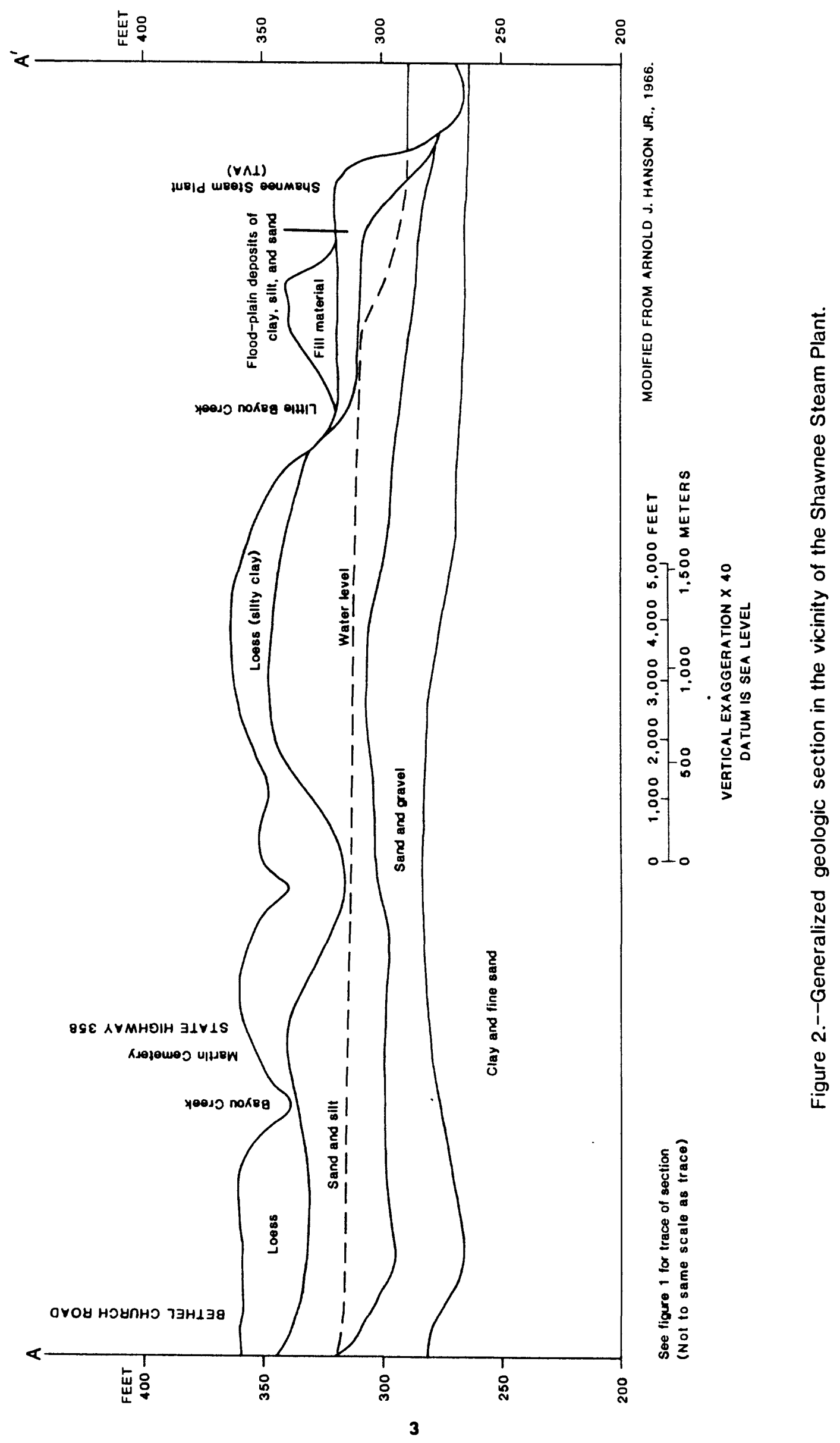


shows the characteristics of the near surface deposits in the area of Bayou and Little Bayou Creeks. For a more complete discussion on geology in the area, the reader is referred to Geologic Quadrangles 561 (Olive, 1966) and 652 (Finch, 1967).

\section{Hydrologic conditions}

Flow in the streams was assumed to be principally from plant releases and ground-water discharge rather than from surface runoff because no significant rainfall occurred in Paducah 8 days prior to and during the seepage study. Releases from the plant were maintained constant during the seepage studies and were verified by frequently monitoring stream stage.

A continuous-record streamflow monitoring station is maintained by the U.S. Geological Survey on the Ohio River at mile 944.1 which is 3.7 miles upstream from the mouth of Bayou Creek. Records at this station show the mean daily elevation of the Ohio River was 292.12 feet above sea leve1 on August 15, 1989, and 292.36 feet on August 16. The elevation of Bayou Creek at its confluence with Little Bayou Creek, which is downstream of the measured stream reaches, is about 300 feet above sea level.

\section{STREAMFLOW}

Streamflow, or discharge, is defined as the volume rate of flow of water, including any substances suspended or dissolved in the water, and is expressed in cubic feet per second $\left(\mathrm{ft}^{3} / \mathrm{s}\right)$. Stream discharge of Bayou and Little Bayou Creeks was measured at approximately 500 to 600 feet increments along channel to describe flow gains or losses between measurement sites.

All discharge measurements were made by wading with current meters. When using this method, observations of width, depth, and velocity are taken at intervals in a cross section of the stream. A current meter measurement is the summation of the products of the subsection areas of the stream cross section and their respective average velocities (Rantz, 1982). Equipment used for measuring flow was checked for accuracy prior to and after the channel surveys and was within acceptable operational limits. The accuracy of individual streamflow measurements was dependent on channel conditions. Measurement error generally was estimated to be less than 10 percent. Discharge is reported to the nearest hundredth for flows less than $1 \mathrm{ft}^{3} / \mathrm{s}$, and to tenths above $1.0 \mathrm{ft}^{3} / \mathrm{s}$.

Apparent gains or losses of flow along the channels can be attributed to one or more of the following: evaporation, unmeasured tributary inflow, diversions, sub-surface flow in unconsolidated channel deposits, interaction with the ground-water system, or measurement error.

The degree of evapotranspiration occurring during the measurement surveys was unknown. An attempt was made to locate and measure all tributary inflows, but due to dense vegetation some tributaries may have been missed. No known flow diversions occurred during the seepage studies. 
Unconsolidated channel deposits of sand and gravel were common in Bayou Creek. In streams with highly permeable unconsolidated channel deposits of sand and gravel, current meter measurements may not reflect total discharge of the stream because flow can occur through the deposits subsurface to the streambed. However, this flow may be contained within the stream channel if impermeable consolidated deposits exist beneath the unconsolidated materials.

Streamflow, measured at 39 main channel sites along Little Bayou Creek on August 15, 1989, ranged from $0.65 \mathrm{ft}^{3} / \mathrm{s}$ at the most upstream site to $1.8 \mathrm{ft}^{3} / \mathrm{s}$ at the most downstream site (table 1, figs. 3 and 4). Tributaries contributed a total of $0.38 \mathrm{ft}^{3} / \mathrm{s}$ in the measured stream reach which extended from about 23,000 to about 5,000 feet upstream from the mouth. Several tributaries were observed to be dry (table 1).

Flow of Little Bayou Creek remained relatively constant in the reach from about 23,000 to about 16,000 feet upstream from the mouth (fig. 4). Measurements indicated lesser flow from about 16,000 to 13,600 feet upstream from the mouth, however this channel reach was relatively deep and measured velocities were below the current meter rating limits. Flow above and below this deep reach of the stream was essentially the same. The flow measurements obtained in the channel reach from about 16,000 to 13,600 feet upstream from the mouth (sites 22 and 23 ) are therefore considered questionable.

Little Bayou Creek showed a general increase in flow from about 13,600 to 5,000 feet upstream from the mouth. Inflow of bank seepage was observed in these lower reaches of the creek.

Discharge measurements of Little Bayou Creek were adjusted to better describe gains and losses of flow along the main channel by subtracting tributary inflow and the flow of the stream measured at the most upstream site (fig. 5). The adjusted discharges shown in figure 5 are reported to hundredths, but no greater accuracy is implied than given in table 1. Differences in streamflow between some measurement sites are within measurement error. The flow for Little Bayou Creek minus the flow at the most upstream measurement site and all tributary inflow was significantly less than zero only in the reach of the stream where the flow data are questionable, and was significantly greater than zero only in the most downstream reaches (fig. 5). Thus, flow from the stream to the ground-water system was not defined and contribution to streamflow from the ground-water system was only indicated in the lower reaches of the channel.

Streamflow, measured at 30 main channel sites along Bayou Creek on August 16,1989 , ranged from $0.30 \mathrm{ft}^{3} / \mathrm{s}$ at the most upstream site to $5.8 \mathrm{ft}^{3} / \mathrm{s}$ at the most downstream site (table 2, figs. 3 and 6 ). Tributaries contributed a total of $5.7 \mathrm{ft}^{3} / \mathrm{s}$ in the measured stream reach which extended from about 24,600 to about 10,200 feet upstream from the mouth. Several tributaries were observed to be dry (table 2). Several channel-bank seeps were noted along the lower channel reach from about 18,200 to 10,000 feet upstream from the mouth, similar to those in the downstream reach of Little Bayou Creek. Two flow measurements exceeded $6 \mathrm{ft}^{3} / \mathrm{s}$ but these measurements were not substantiated by adjacent measurements and could be in error. One of these measurements (at site 52) was the last measurement made during the seepage study and several velocities were obtained hurriedly in order to complete the measurement prior to an impending rainstorm. 
Table 1.--Discharge, specific-conductance, and temperature measurements in the Little Bayou Creek watershed, August 15, 1989

[Q, discharge in cubic feet per second; SC, specific conductance in microsiemens per centimeter at 25 degrees Celsius; $T$, temperature in degrees Celsius; distance is in feet. Site numbers refer to figure 3 ]

\begin{tabular}{|c|c|c|c|c|c|c|c|c|c|}
\hline $\begin{array}{l}\text { Site } \\
\text { number }\end{array}$ & $\begin{array}{l}\text { Distance } \\
\text { above } \\
\text { mouth }\end{array}$ & Remarks & 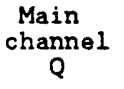 & $\begin{array}{c}\text { Tributary } \\
Q\end{array}$ & $\begin{array}{l}\text { Main } \\
\text { channel } \\
\text { SC }\end{array}$ & $\begin{array}{l}\text { Tributary } \\
\text { SC }\end{array}$ & $\begin{array}{l}\text { Main } \\
\text { channel } \\
T\end{array}$ & $\underset{T}{\text { Tributary }}$ & Time \\
\hline 1 & $\begin{array}{l}23,090 \\
22,960\end{array}$ & $\begin{array}{l}\text { Ten feet above flume } \\
\text { Dry right tributary }\end{array}$ & 0.65 & & 231 & & 23.0 & & 0655 \\
\hline 2 & $\begin{array}{l}22,740 \\
22,410\end{array}$ & Farm road bridge & .72 & & 238 & & 22.9 & & 0740 \\
\hline $\begin{array}{l}3 \\
4\end{array}$ & $\begin{array}{l}22,280 \\
21,830 \\
21,460\end{array}$ & Dry left tributary & $\begin{array}{l}.64 \\
.75\end{array}$ & & $\begin{array}{l}238 \\
238\end{array}$ & & $\begin{array}{l}22.8 \\
22.7\end{array}$ & & $\begin{array}{l}0815 \\
0847\end{array}$ \\
\hline $\begin{array}{l}5 \\
6\end{array}$ & $\begin{array}{l}21,380 \\
20,910 \\
20,670\end{array}$ & Dry right tributary & $\begin{array}{l}.64 \\
.62\end{array}$ & & $\begin{array}{l}238 \\
237\end{array}$ & & $\begin{array}{l}22.7 \\
22.6\end{array}$ & & $\begin{array}{l}0914 \\
0945\end{array}$ \\
\hline 7 & $\begin{array}{l}20,520 \\
20,280\end{array}$ & Dry left tributary & .64 & & 238 & & 22.7 & & 1015 \\
\hline 8 & $\begin{array}{l}20,150 \\
20,050 \\
19,970\end{array}$ & $\begin{array}{l}\text { Dry right tributary } \\
\text { Dry right tributary }\end{array}$ & .65 & & 238 & & 22.7 & & 1050 \\
\hline $\begin{array}{r}9 \\
10 \\
11 \\
12\end{array}$ & $\begin{array}{l}19,840 \\
19,490 \\
19,150 \\
18,800 \\
18,430\end{array}$ & Dry right tributary & $\begin{array}{l}.69 \\
.75 \\
.74 \\
.63\end{array}$ & & $\begin{array}{l}238 \\
238 \\
239 \\
236\end{array}$ & & $\begin{array}{l}22.7 \\
23.1 \\
23.5 \\
23.4\end{array}$ & & $\begin{array}{l}1115 \\
1143 \\
1221 \\
1252\end{array}$ \\
\hline 13 & $\begin{array}{l}18,400 \\
18,270\end{array}$ & Dry right tributary & .64 & & 240 & & 24.1 & & 1325 \\
\hline 14 & $\begin{array}{l}18,050 \\
17,720\end{array}$ & Dry left tributary & .74 & & 240 & & 24.2 & & 1354 \\
\hline $\begin{array}{l}15 \\
16 \\
17\end{array}$ & $\begin{array}{l}17,720 \\
17,160 \\
16,750 \\
16,710 \\
16,530\end{array}$ & $\begin{array}{l}\text { Deep from A15 to A16 } \\
\text { Dry right tributary } \\
\text { Dry left tributary }\end{array}$ & $\begin{array}{l}.79 \\
.70 \\
.74\end{array}$ & & $\begin{array}{l}238 \\
227 \\
231\end{array}$ & & $\begin{array}{l}23.9 \\
23.2 \\
22.7\end{array}$ & & $\begin{array}{l}1420 \\
1500 \\
1535\end{array}$ \\
\hline $\begin{array}{l}18 \\
19 \\
20\end{array}$ & $\begin{array}{l}16,350 \\
15,650 \\
14,960 \\
14,650\end{array}$ & $\begin{array}{l}\text { Too deep for } Q \text { measurement } \\
\text { Too deep for } Q \text { measurement } \\
\text { Dry left tributary }\end{array}$ & .67 & & $\begin{array}{l}226 \\
243 \\
240\end{array}$ & & $\begin{array}{l}22.7 \\
24.4 \\
23.7\end{array}$ & & 1608 \\
\hline $\begin{array}{l}21 \\
22 \\
23\end{array}$ & $\begin{array}{l}14,430 \\
14,190 \\
13,830 \\
13,780 \\
13,650\end{array}$ & $\begin{array}{l}\text { Too deep for } Q \text { measurement } \\
\text { Measurement questionable } \\
\text { Measurement questionable } \\
\text { Dry right tributary } \\
\text { Dry left tributary }\end{array}$ & $\begin{array}{l}.13 \\
.35\end{array}$ & & $\begin{array}{l}245 \\
211 \\
226\end{array}$ & & $\begin{array}{l}24.9 \\
23.5 \\
22.3\end{array}$ & & $\begin{array}{l}1100 \\
0940\end{array}$ \\
\hline $\begin{array}{l}24 \\
25\end{array}$ & $\begin{array}{l}13,540 \\
13,320 \\
13,190\end{array}$ & Dry left tributary & $\begin{array}{l}.74 \\
.65\end{array}$ & & $\begin{array}{l}224 \\
222\end{array}$ & & $\begin{array}{l}21.8 \\
21.6\end{array}$ & & $\begin{array}{l}0845 \\
0805\end{array}$ \\
\hline 26 & $\begin{array}{l}12,970 \\
12,720 \\
12,680\end{array}$ & $\begin{array}{l}\text { Dry left tributary } \\
\text { Bridge }\end{array}$ & .63 & & 221 & & 21.6 & & 0715 \\
\hline 27 & $\begin{array}{l}12,670 \\
12,540 \\
12,530\end{array}$ & $\begin{array}{l}\text { Five feet below bridge } \\
\text { Above tributary } \\
\text { Tributary }\end{array}$ & .62 & 0.22 & $\begin{array}{l}216 \\
219\end{array}$ & 217 & 21.0 & & $\begin{array}{l}0725 \\
0740\end{array}$ \\
\hline $\begin{array}{l}28 \\
29 \\
30 \\
31 \\
32 \\
33 \\
34 \\
35\end{array}$ & $\begin{array}{r}12,310 \\
11,920 \\
11,530 \\
11,150 \\
10,780 \\
10,420 \\
10,000 \\
9,580 \\
9,160\end{array}$ & Above spring & $\begin{array}{r}.95 \\
.80 \\
1.2 \\
1.0 \\
1.1 \\
.85 \\
.92 \\
1.1\end{array}$ & 0.22 & $\begin{array}{l}216 \\
226 \\
226 \\
225 \\
225 \\
223 \\
223 \\
220 \\
228\end{array}$ & 211 & $\begin{array}{l}21.5 \\
22.2 \\
22.4 \\
22.6 \\
22.7 \\
22.6 \\
22.8 \\
23.5\end{array}$ & & $\begin{array}{l}0815 \\
0845 \\
0922 \\
0952 \\
1020 \\
1100 \\
1158 \\
1238\end{array}$ \\
\hline 36 & $\begin{array}{l}9,150 \\
9,090 \\
8,690\end{array}$ & $\begin{array}{l}\text { Spring } \\
\text { Dry right tributary }\end{array}$ & & .16 & 233 & 266 & 22.1 & 14.5 & $\begin{array}{l}1300 \\
1235\end{array}$ \\
\hline 37 & $\begin{array}{l}8,660 \\
8,540\end{array}$ & Water line & 1.2 & & 236 & & 21.5 & & 1220 \\
\hline $\begin{array}{l}38 \\
39\end{array}$ & $\begin{array}{l}8,260 \\
7,870 \\
7,750\end{array}$ & Dry left tributary & $\begin{array}{l}1.3 \\
1.2\end{array}$ & & $\begin{array}{l}240 \\
242\end{array}$ & & $\begin{array}{l}21.5 \\
21.9\end{array}$ & & $\begin{array}{l}1145 \\
1110\end{array}$ \\
\hline $\begin{array}{l}40 \\
41 \\
42 \\
43 \\
44\end{array}$ & $\begin{array}{l}7,480 \\
6,920 \\
6,410 \\
5,940 \\
5,510\end{array}$ & & $\begin{array}{l}1.4 \\
1.2 \\
1.6 \\
1.8\end{array}$ & & $\begin{array}{l}248 \\
251 \\
258 \\
272 \\
271\end{array}$ & & $\begin{array}{l}21.5 \\
20.3 \\
19.7 \\
19.5 \\
19.5\end{array}$ & & $\begin{array}{l}1035 \\
1000 \\
0910 \\
0825 \\
0750\end{array}$ \\
\hline
\end{tabular}




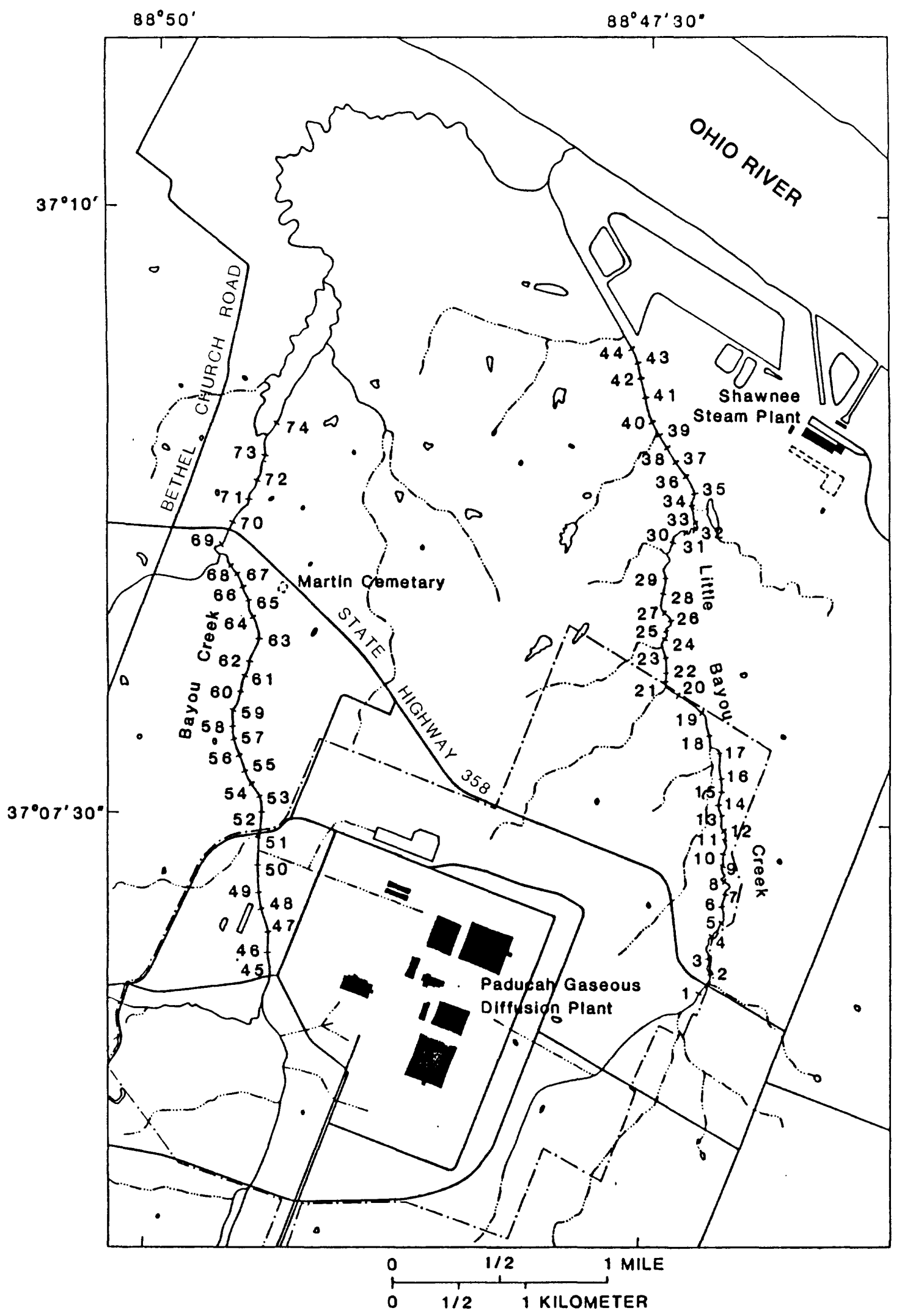

Base from U.S.Geological Survey 1:24,000, Heath, 1978 , Joppa, 1982.

Figure 3.--Location of measurement sites in the Bayou Creek and Little Bayou Creek watersheds, August 15 and 16, 1989. 


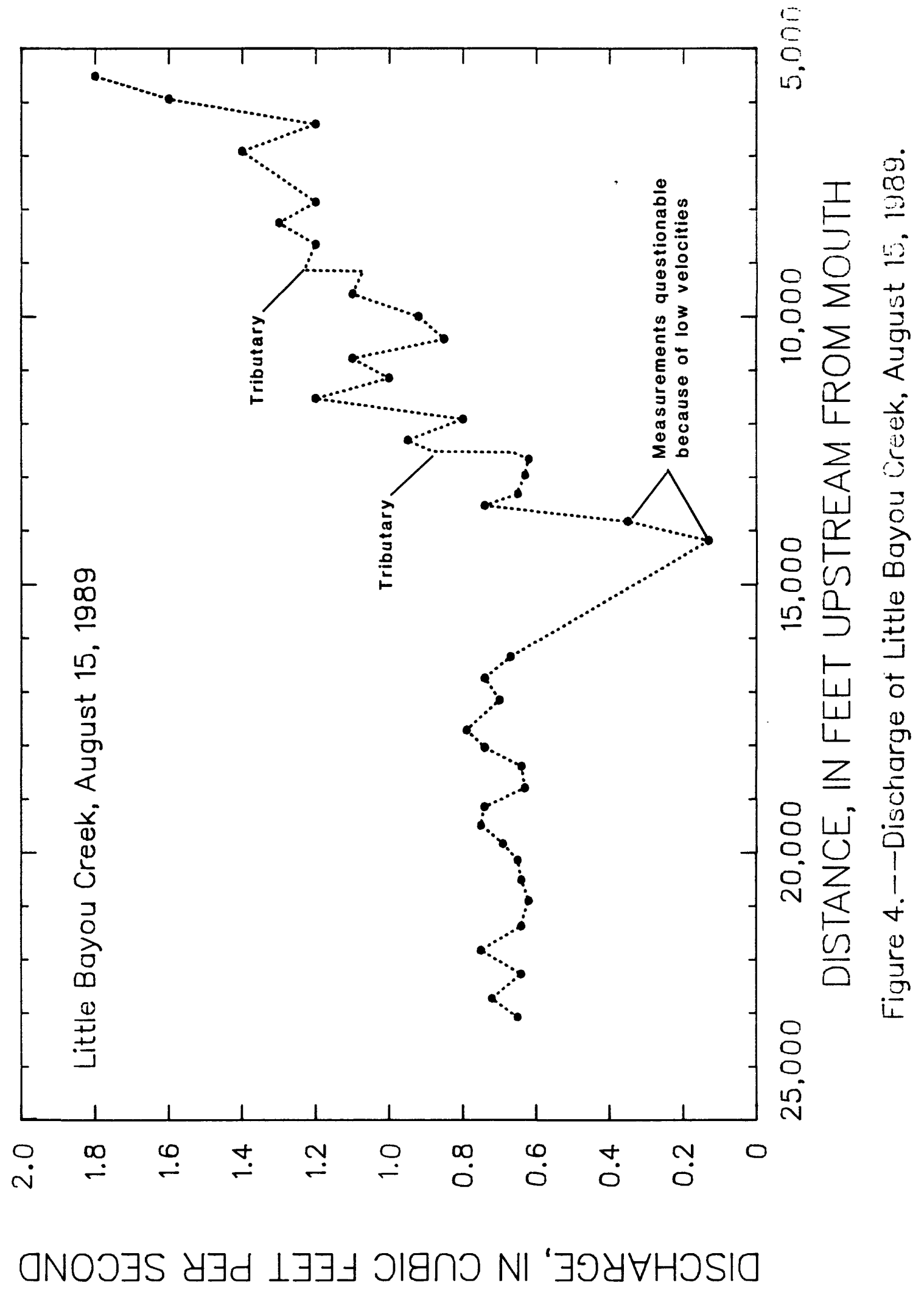




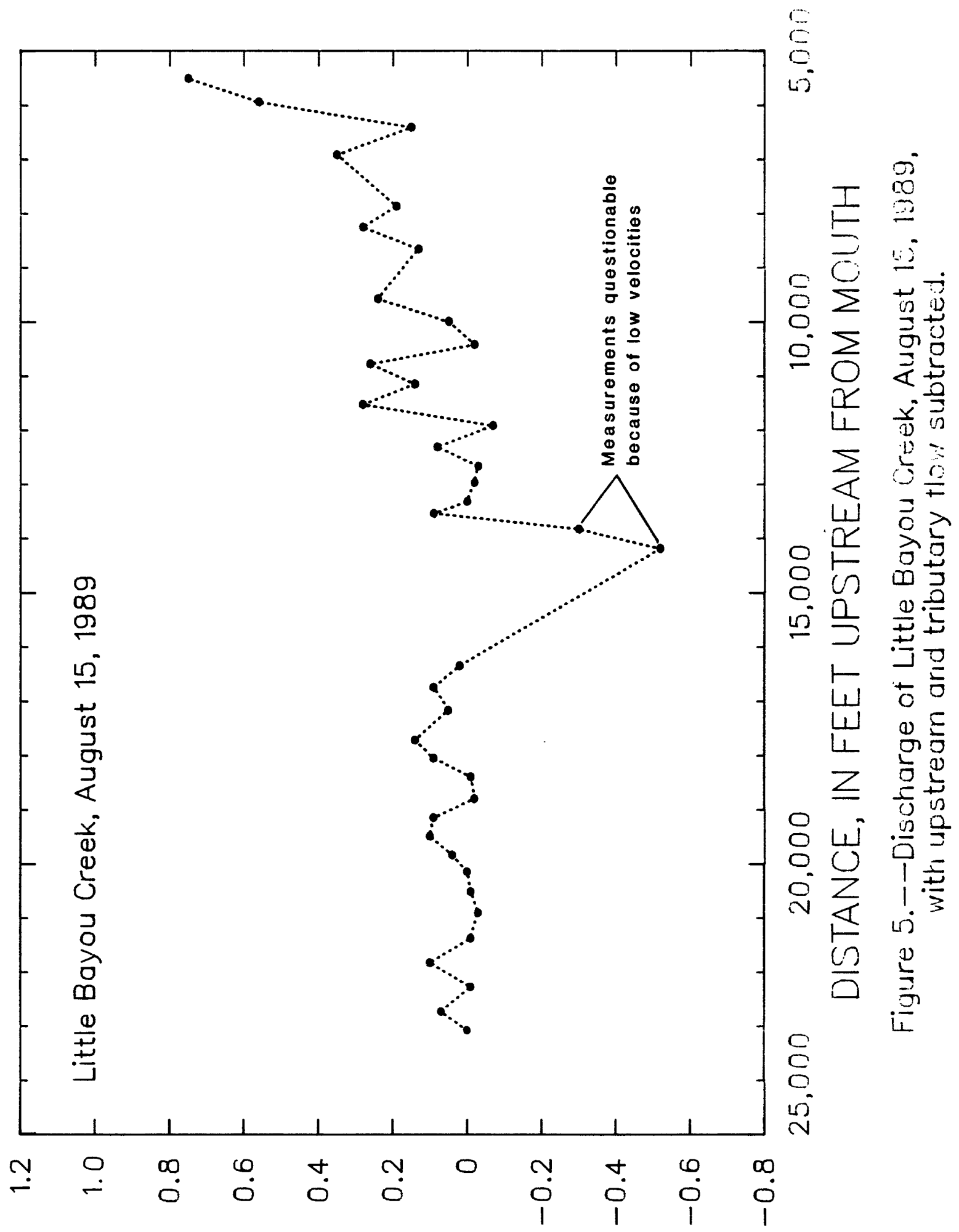

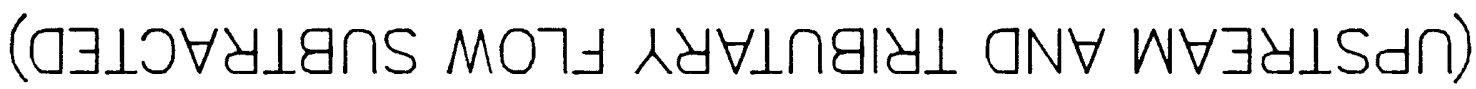 aNOJ $\exists S$ d $\exists d 1 \exists \exists \exists$ JIgnJ NI ' $\exists$ J $\forall \forall H O S I O$}


Table 2.--Discharge, specific-conductance, and temperature measurements in the Bayou Creek watershed, August 16, 1989

[Q, discharge in cubic feet per second; SC, specific conductance in microsiemens per centimeter at 25 degrees Celsius; $T$, temperature in degrees Celsius; distance is in feet. Site numbers refer to figure 3 ]

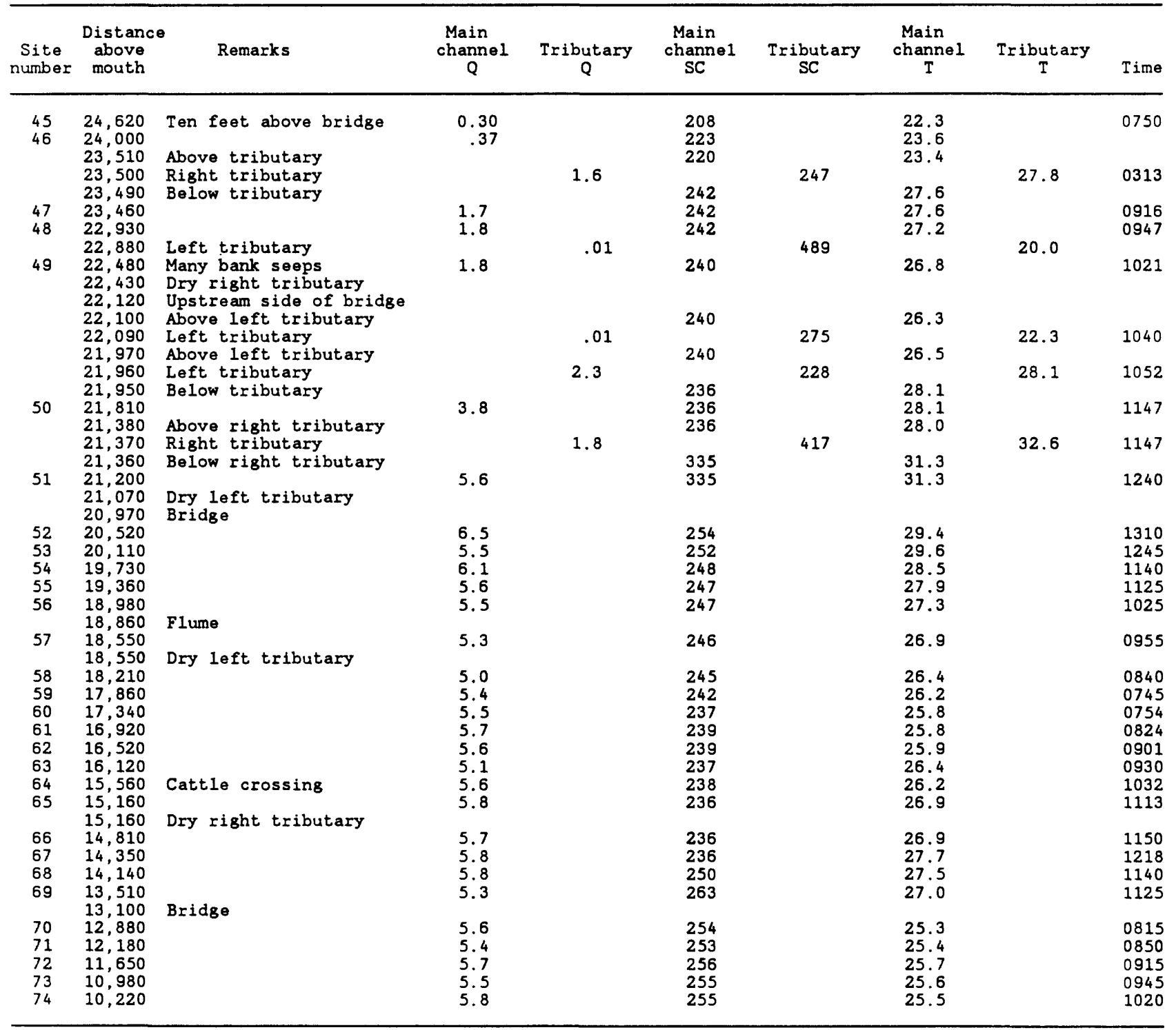




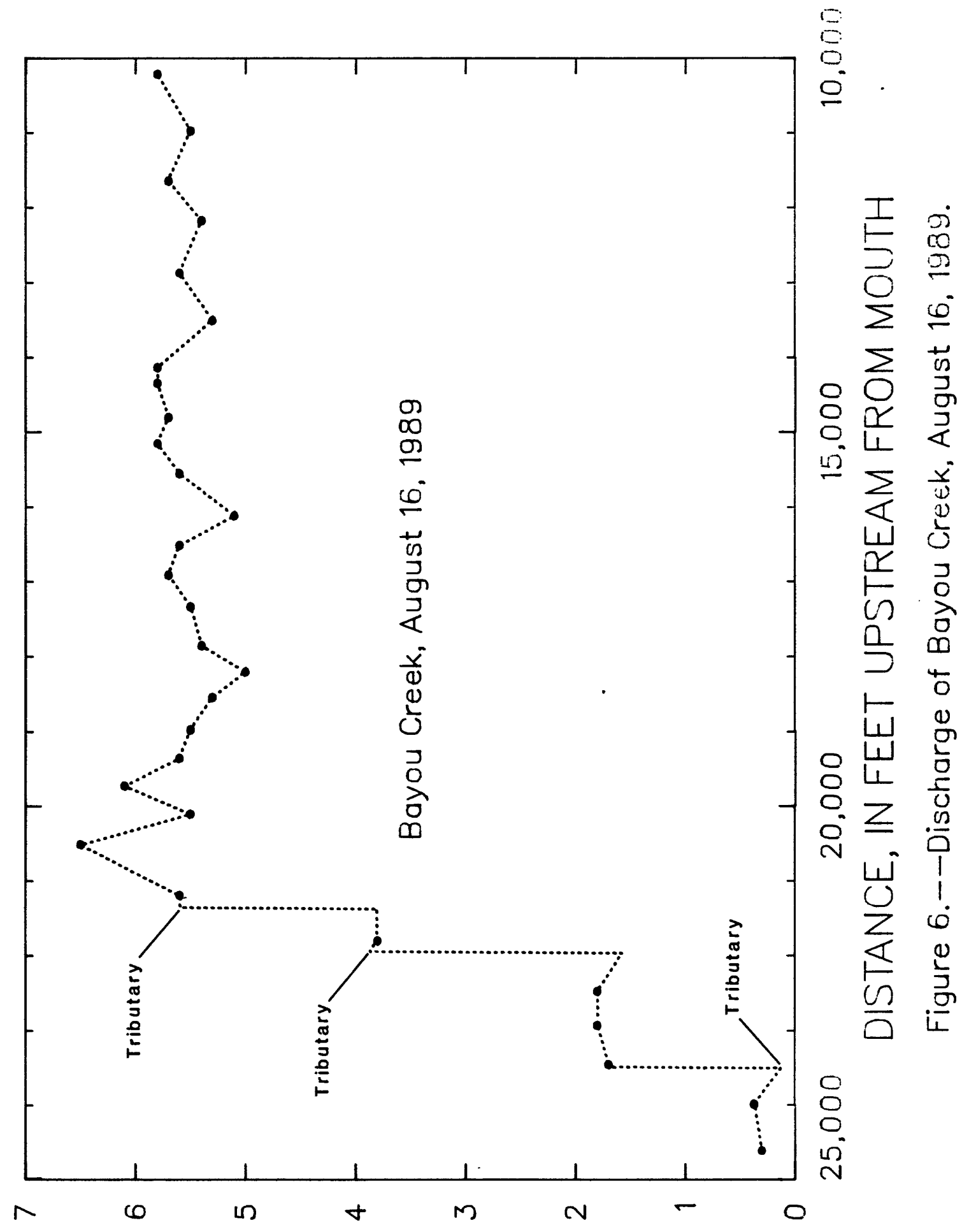

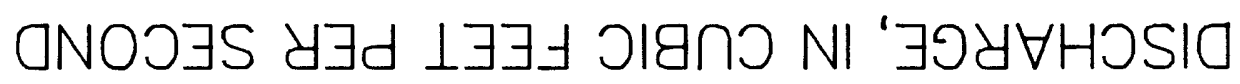


Flow measurements of Bayou Creek were adjusted to better describe gains and losses of flow along the main channel by subtracting tributary inflow and the flow of the stream measured at the most upstream site (fig. 7). The adjusted discharges shown in figure 7 are reported to hundredths, but no greater accuracy is implied than given in table 2. Small calculated differences between individual measurements may be within measurement error. The flow of Bayou Creek minus the flow at the most upstream measurement site and all tributary inflow was less than zero for most sites on the main channel (fig. 7). This indicates that water may have been moving from the stream to the ground-water system. However, some flow variations described by the measurements probably resulted from unmeasured sub-surface flow in unconsolidated channel materials (sand and gravel) which were observed at many measurement sites.

\section{SPECIFIC CONDUCTANCE}

Specific conductance is a measure of the ability of a water to conduct an. electrical current. It is expressed in microsiemens per centimeter at 25 degrees Celsius $(\mu \mathrm{S} / \mathrm{cm})$. Specific conductance is related to the type and concentration of ions in solution and was measured to help detect locations of ground-water discharge to the streams and to distinguish between re-emergence of channel flow and spring flow. Based on comparisons to laboratory standards prior to and at the conclusion of the study, corrections were applied to the field data for specific conductance.

Specific conductance was measured on August 15, 1989, upstream from and in two tributaries to Little Bayou Creek, and at 44 additional sites in Little Bayou Creek (table 1, figs. 3 and 8). Specific conductance in the Little Bayou Creek watershed ranged from 211 to $272 \mu \mathrm{S} / \mathrm{cm}$. Specific conductance remained relatively constant from about 23,000 to 17,700 feet upstream from the mouth. A deep pool was observed from about 17,700 to 17,200 feet upstream from the mouth and the specific conductance of water below this pool was lower than that above it. The channel was also deep from about 16,600 to 13,600 feet upstream from the mouth and specific conductance was variable in this reach. Although flow of Little Bayou Creek showed a general increase in the reach from about 13,600 to 5,000 feet upstream from the mouth, specific conductance did not show a consistent pattern (fig. 8). Variable specificconductance values were observed from about 13,600 to 10,000 feet upstream from the mouth. Increasing specific conductance was measured from about 10,000 to 5,000 feet upstream from the mouth, which is the area in which many bank seeps were observed. One spring about 9,150 feet above the mouth had a specific conductance of $266 \mu \mathrm{S} / \mathrm{cm}$.

Specific conductance measurements were made August 16, 1989, at sites just upstream and downstream from five tributaries to Bayou Creek, sites in these tributaries, and at 30 additional sites in Bayou Creek (table 2, figs. 3 and 9). Specific conductance of the Bayou Creek mainstem ranged from 208 to $335 \mu \mathrm{S} / \mathrm{cm}$. One small tributary about 22,880 feet upstream from the mouth had a specific conductance of $489 \mu \mathrm{S} / \mathrm{cm}$, and one relatively large tributary 21,370 feet upstream from the mouth (probably plant discharge) had a specific conductance of $417 \mu \mathrm{S} / \mathrm{cm}$. 


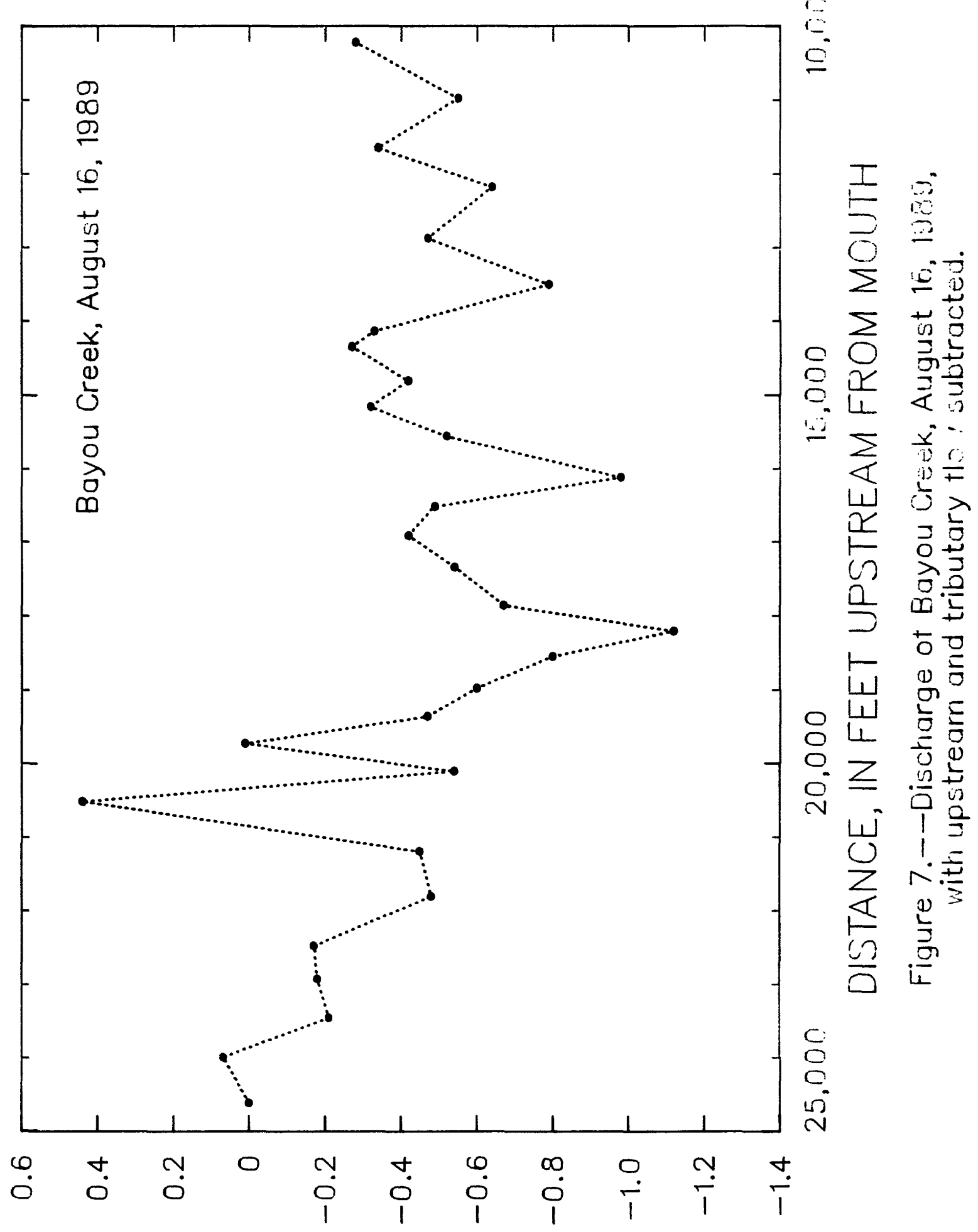

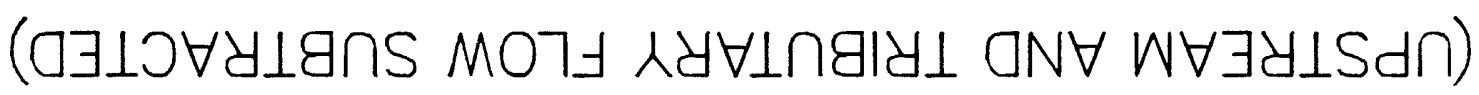

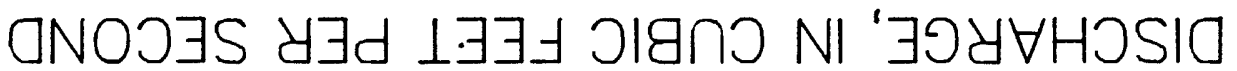




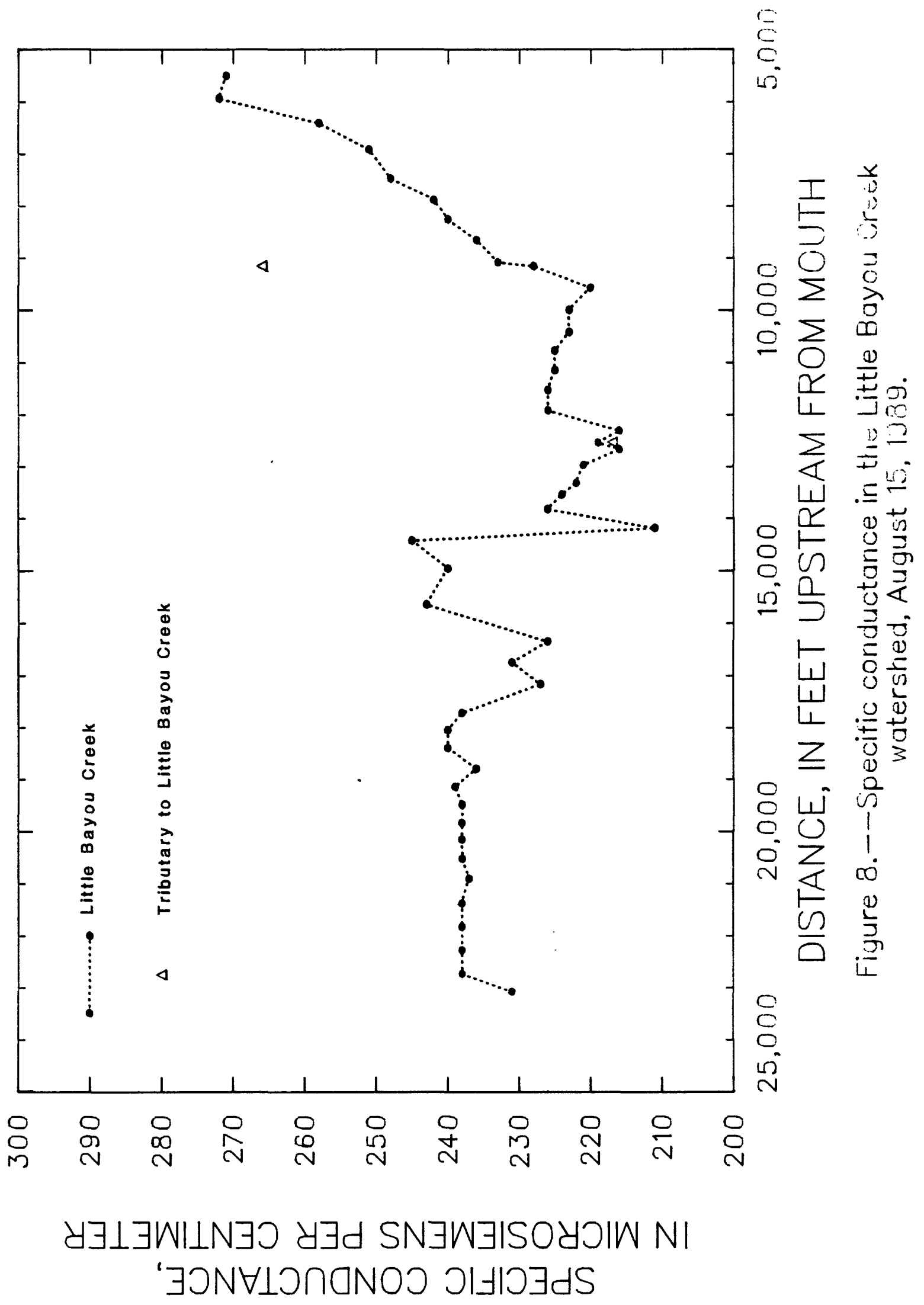




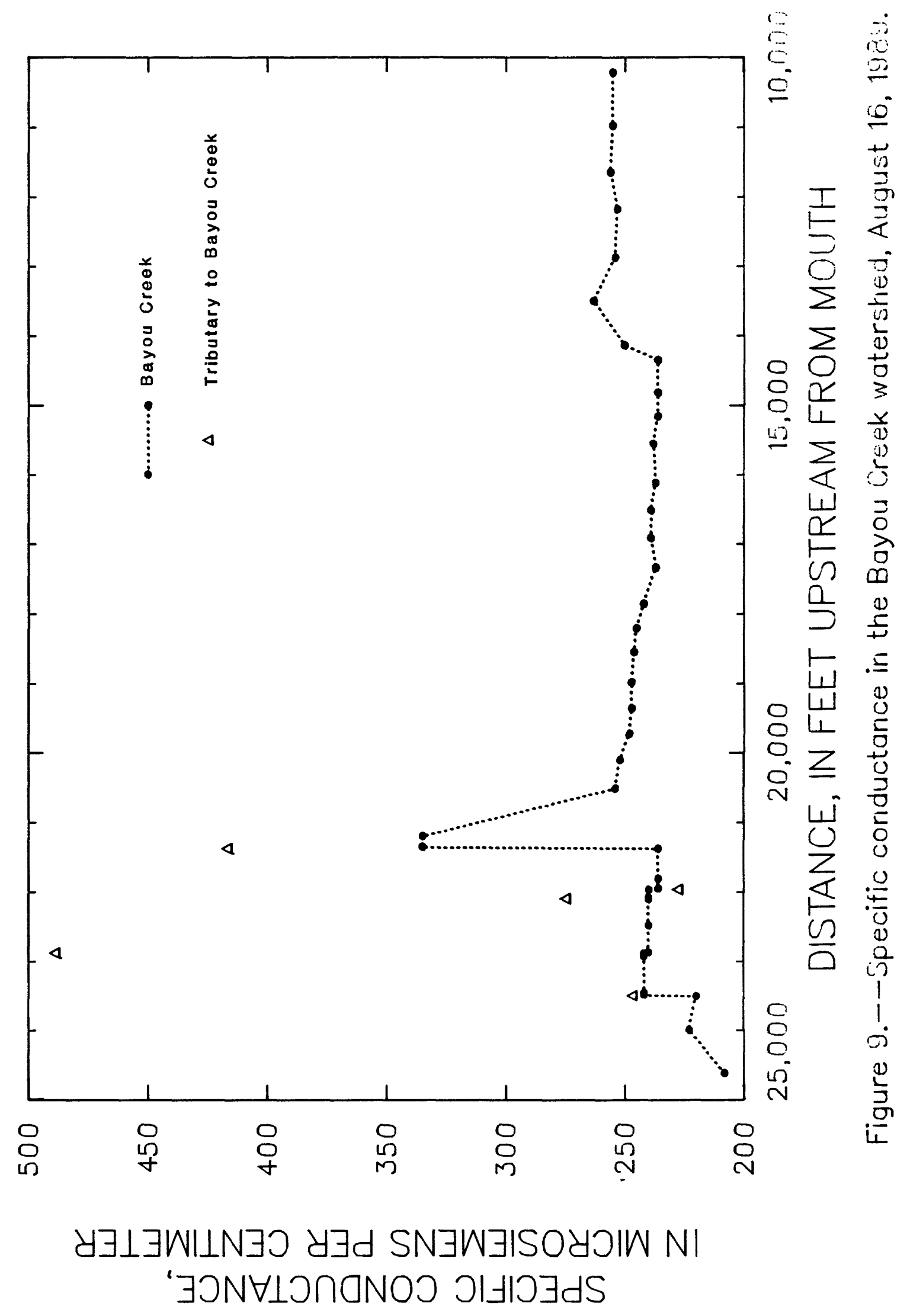




\section{TEMPERATURE}

Water temperature was measured to help detect locations of ground-water discharge to the streams and to distinguish between re-emergence of channel flow and spring flow. Temperature was measured in degrees Celsius $\left({ }^{\circ} \mathrm{C}\right)$ using meters which had previously been checked against laboratory thermometers.

Temperature was measured on August 15, 1989, upstream of and in two tributaries to Little Bayou Creek, and at 44 additional sites in Little Bayou Creek (table 1, figs. 3 and 10). Water temperature in Little Bayou Creek ranged from 19.5 to $24.9^{\circ} \mathrm{C}$. The temperature of the deep pool areas was variable. Decreasing water temperature was observed from about 10,000 to 5,000 feet upstream from the mouth (fig. 10), which is the area in which many bank seeps were observed. The spring about 9,150 feet upstream from the mouth had a temperature of $14.5^{\circ} \mathrm{C}$ which indicates that it was not re-emergence of channel flow. Some temperature variations along the channel shown in figure 10 may simply reflect solar warming during the time of study.

Measurements of water temperature were obtained August 16, 1989, at sites just upstream and downstream from five tributaries to Bayou Creek, sites in the tributaries, and at 30 additional sites in Bayou Creek (table 2, figs. 3 and 11). Water temperature in Bayou Creek ranged from 22.3 to $31.3^{\circ} \mathrm{C}$. The tributary about 21,370 feet upstream from the mouth (probably plant discharge) had a temperature of $32.6^{\circ} \mathrm{C}$. Some temperature increases or decreases along the channel (fig. 11) may be related to time of measurement and warming during the day. For example, the temperature decreased from $27.0^{\circ} \mathrm{C}$ at site 69 $\left(13,510\right.$ feet upstream from the mouth) to $25.3^{\circ} \mathrm{C}$ at site $70(12,880$ feet upstream from the mouth) (table 2 and fig. 11), but the temperature measurement at site 70 was obtained about 3 hours earlier than the measurement at site 69 . 


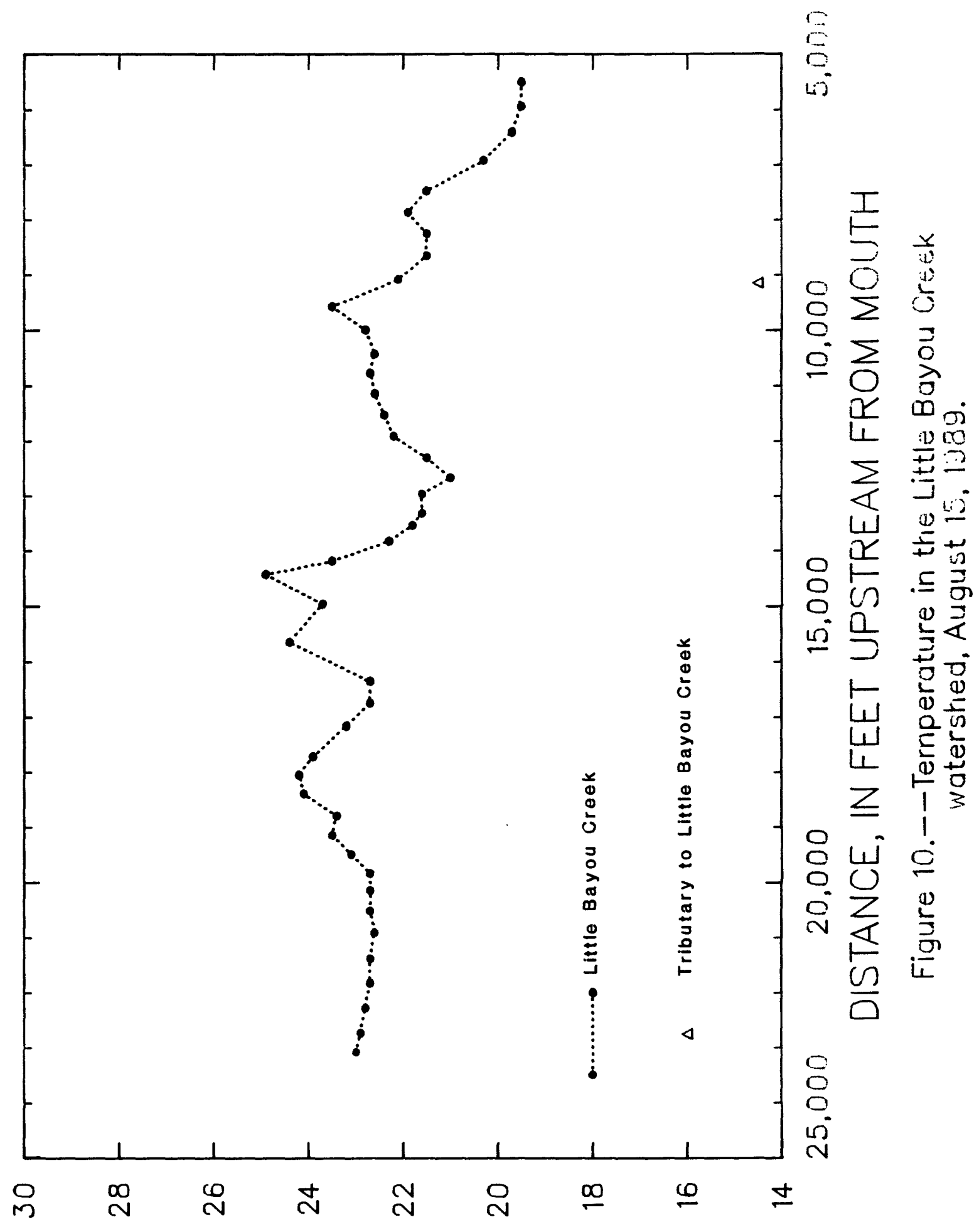

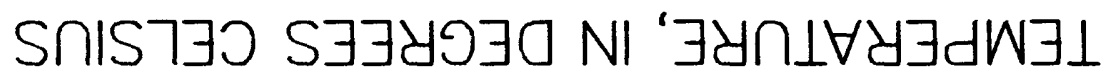




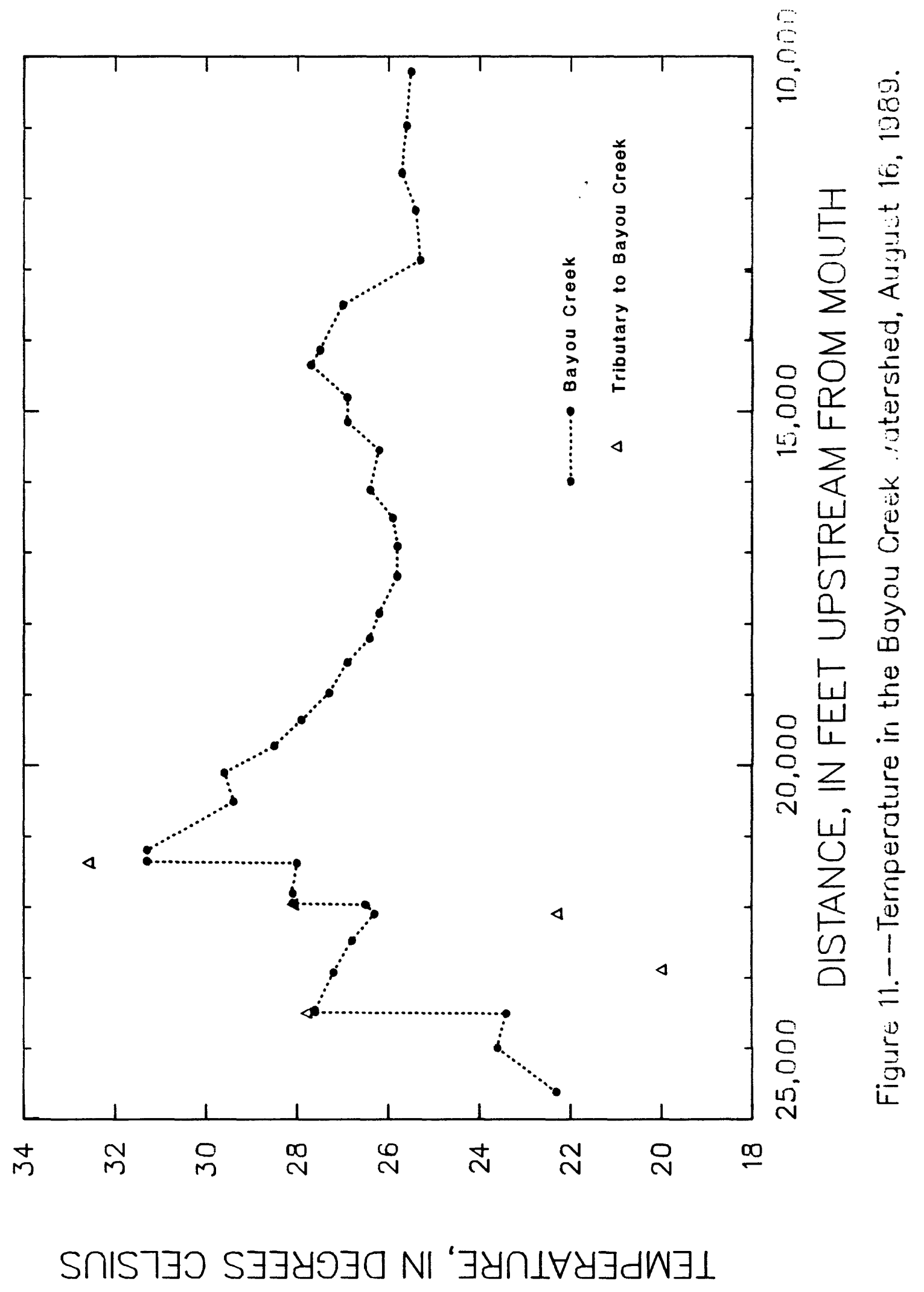




\section{REFERENCES}

Finch, Warren, I., 1967, Geologic map of the Joppa quadrangle: U.S. Geological Survey Geologic Quadrangle Map GQ-652.

Hanson, Arnold J., Jr., 1966, Availability of ground water in the Kentucky parts of the Joppa and Metropolis quadrangles, Jackson Purchase Region, Kentucky: U.S. Geological Survey Hydrologic Investigation Atlas HA-171.

01ive, Welds W., 1966, Geologic map of the Heath quadrangle: U.S. Geological Survey Geologic Quadrangle Map GQ-561.

Rantz, S.E., 1982, Measurement and computation of streamflow: Volume 1. Measurement of stage and discharge: U.S. Geological Survey Water-Supply Paper 2175, p. 79-183. 